\title{
STYLOMETRY: STATISTICAL APPROACH INTO FILM STYLE
}

\author{
Muhammad Yunus Patawari ${ }^{1}$ \\ ${ }^{1}$ Lembaga IImu Pengetahuan Indonesia (BIT-LIPI) \\ E-mail: yunus_pattawari@yahoo.co.id
}

\begin{abstract}
So far the study of cinema is still dominated by the use of a Narrative Analysis approach, where its weaknesses do not have empirical evidences, so the resulting analysis is assumptions which then followed by a text debate. Statistical Style Analysis or Stylometry is an alternative method in the study of cinema used to measure the director's formal (film style) parameters. This study applied Stylometry to the films by Chaerul Umam for decades (1970-2000). From this study it was found statistically that the Chaerul Umam style film underwent a change in the use of zoom techniques, the dominance of the use of medium shot (MS) and classified as small ASL units under 9 seconds / shot which is 6.6 / seconds.
\end{abstract}

Keywords: Stylometry, film style, quantitative, and statistic

\begin{abstract}
ABSTRAK
Sejauh ini kajian sinema masih didominasi oleh penggunaan pendekatan analisis teksnaratif, di mana kelemahannya tidak memiliki bukti empirik, sehingga analisis yang dihasilkan bersifat asumsi yang kemudian melahirkan debat teks. Statistical Style Analysis atau Stylometry merupakan metode alternatif dalam kajian sinema yang digunakan untuk mengukur parameter formal (film style) sutradara. Studi ini mengaplikasikan Stylometry pada film-film karya Chaerul Umam selama beberapa dekade (1970-2000). Dari kajian ini ditemukan secara statistic bahwa film style Chaerul Umam mengalami perubahan dalam penggunaan teknik zoom, dominasi penggunaan medium shot (MS) dan tergolong dalam satuan ASL kecil di bawah 9 detik/shot yaitu 6.6 /detik.
\end{abstract}

Kata kunci: Stylometry, film style, kuantitatif, dan statistik.

\section{PENDAHULUAN}

Beberapa dekade ini kajian sinema telah ditarik begitu jauh ke dalam ranah interpretasi naratif. Melalui narasinya, film dipandang sebagai mesin pencerita yang tidak berbeda dengan karya seni sastra dan teater. Karena itu, analisis naratif film banyak mengadopsi teori sastra seperti Semiotika, dan Hermeneutika sebagai pisau analisisnya. Hadirnya Cultural Studies membawa kajian sinema pada level lebih Ianjut. Dalam Cultural Studies, film dipandang sebagai produk kebudayaan yang menggandeng 'misi' terselubung, karena itu film dikupas melalui teori-teori sosial seperti teori Marxis, Structuralism, Postmodernism, Feminism, dll. Tidak jarang, film dipandang sebagai sebuah fenomena sosial. Dalam pandangan Fenomenologi ini, film dianggap menampilkan dunia intersubjektif (hubungan antar individu) yang harus dimaknai. Melalui pendekatan ini, tidak jarang 'menyeret' latar belakang pembuat film (author) sebagai individu yang bertanggung jawab terhadap gejala-gejala 


\section{CAPTURE}

sosial yang ditampilkan dalam filmnya.

Teori-teori tersebut menempatkan peneliti sebagai instrumen utama, maka penelitian kualitatif bersifat deskriptif dan cenderung menggunakan analisis dengan pendekatan induktif. Sayangnya, hasil penelitian kualitatif tidak dapat digeneralisir untuk kepentingan penelitian yang lain, sebab metode ini tidak bertitik-tolak dari sampel. Kelemahan paling mendasar dalam menggunakan persepsi dan interpretasi dalam kajian sinema hanya akan memetakan film menjadi dua kelas; yang bagus dan yang buruk seperti yang dilakukan oleh teori Auteur yang dipopulerkan oleh Andrew Sarris. Sehingga, sutradara auteur pasti lebih unggul dibanding sutradara yang bukan auteur.

Pendekatan yang biasa digunakan dalam kajian sinema seperti yang dibahas sebelumnya merupakan varian penelitian kualitatif dalam paradigma interpretatif. Sementara itu, penelitian yang menggunakan pendekatan kuantitatif (positivism) masih jarang. Penelitian kuantitatif menawarkan hasil yang lebih stabil dibanding penelitian kualitatif yang sangat tergantung pada kualitas analisis penelitinya, karena itu hasil penelitian kualitatif memiliki kecenderungan terjebak pada subjektivitas penelitinya. Perbedaan pandangan dasar (aksioma) antara penelitian kualitatif dan kuantitatif dapat dilihat dari table berikut (Sugiyono 2012):
Tabel 1 : Aksioma penelitian kuantitatif dan kualitatif

\begin{tabular}{|c|c|c|}
\hline Aksioma & $\begin{array}{c}\text { Metode } \\
\text { Kuantitatif }\end{array}$ & $\begin{array}{l}\text { Metode } \\
\text { Kualitatif }\end{array}$ \\
\hline Sifat Realistis & $\begin{array}{l}\text { Dapat } \\
\text { diklasifikasikan, } \\
\text { konkrit, } \\
\text { teramati, } \\
\text { terukur }\end{array}$ & $\begin{array}{l}\text { Ganda, } \\
\text { holistik, } \\
\text { dinamis, } \\
\text { hasil } \\
\text { konstruksi } \\
\text { dan } \\
\text { pemahaman }\end{array}$ \\
\hline $\begin{array}{l}\text { Hubungan } \\
\text { peneliti } \\
\text { dengan yang } \\
\text { diteliti }\end{array}$ & $\begin{array}{l}\text { Independen, } \\
\text { supaya } \\
\text { terbangun } \\
\text { objektivitas }\end{array}$ & $\begin{array}{l}\text { Interaktif } \\
\text { dengan } \\
\text { sumber data } \\
\text { supaya } \\
\text { memperoleh } \\
\text { makna }\end{array}$ \\
\hline $\begin{array}{l}\text { Hubungan } \\
\text { variabel }\end{array}$ & Sebab-akibat & $\begin{array}{l}\text { Timbal balik/ } \\
\text { interaktif/ }\end{array}$ \\
\hline $\begin{array}{l}\text { Kemungkinan } \\
\text { generalisasi }\end{array}$ & $\begin{array}{l}\text { Cendrung } \\
\text { membuat } \\
\text { generalisasi }\end{array}$ & $\begin{array}{l}\text { Hanya } \\
\text { mungkin } \\
\text { dalam ikatan } \\
\text { konteks dan } \\
\text { waktu. }\end{array}$ \\
\hline Peranan nilai & $\begin{array}{l}\text { Cenderung } \\
\text { bebas nilai }\end{array}$ & $\begin{array}{l}\text { Terkait nilai- } \\
\text { nilai yang } \\
\text { dibawa } \\
\text { peneliti dan } \\
\text { sumber } \\
\text { data. }\end{array}$ \\
\hline
\end{tabular}

Landasan filosofis penelitian kualitatif berasal dari paradigma Fenomenologi yang memandang subjek dan objek tidak dapat dipisahkan dan aktif bersama dalam memahami berbagai gejala (Hasbiansya 2008). Dari sudut penilaiannya, Fenomenologi mensyaratkan agar penelitian selalu terikat oleh nilai, sehingga hasil penelitiannya harus dilihat sesuai konteks. Berbeda dengan penelitian kuantitatif yang berasal dari paradigma Positivisme yang mensyaratkan pemisahan antara subjek peneliti dan objek yang diteliti untuk memperoleh hasil yang objektif. Positivisme juga mensyaratkan penelitian 
yang bebas nilai agar mencapai objektivitas sehingga tingkat keberlakuan hasil penelitiannya tidak terikat tempat dan waktu atau bersifat universal.

Kajian sinema yang diakui sebagai sebuah bidang studi pada tahun 1950-an, telah mengalami dialektika antara film dengan filsafat Fenemenologi, Psikologi, Estetika dan Sosiologi, namun bagi Christian Metz, teori film yang ada belum cukup memenuhi kriteria sebagai metode ilmiah. Karena, untuk menjadi disiplin ilmu yang mapan harus ada metode objektif yang tidak tergoyahkan dalam menganalisis film (Ariansah 2016). Metz dan tokoh Formalis lainnya memilih melakukan klaim/pengandaian ontologis terkait esensi film sebagai langkah awal kontruksi teori dalam bingkai Fenomenologi yang berada dalam payung paradigma kualitatif. Alih-alih menikuti jejak Metz, Barry Salt dalam buku Film Style and Technology: History and Analysis (2009) memperkenalkan Statistical Style Analysis atau Stylometry sebagai metode analisis film dengan pendekatan kuantitatif.

\section{TINJAUAN TEORI}

Tulisan ini tidak akan membahas silang sengkarut antara penelitian kualitatif dan kuantitatif, melainkan memberi penjabaran mengenai Stylometry sebagai pendekatan metodelogi ilmiah dalam kajian sinema. Pertama kali Stylometry diperkenalkan oleh Barry Salt seorang doktor di bidang Fisika teoritis kelahiran
Melbourne, Australia. Metode Stylometry yang dikembangkan Salt merupakan tesis yang diajukannya ketika masih di London School of Film Technique tahun 1968. Salt mensinergiskan latar belakang intelektualnya di bidang sains yaitu Fisika dan Matematika. Menurutnya, dalam bidang sains, pandangan realitas dan dunia nyata merupakan hubungan pararel dengan teknologi. Bagi Salt, sulit memisahkan pembahasan tentang sejarah perkembangan style film tanpa menghubungkannya dengan teknologi, karena itu dalam penerapan Stylometry diperlukan pemahaman teknis tentang film itu sendiri.

Barry Salt mendudukkan pendekatan sainsnya tersebut ke dalam filsafat materialisme namun bukan merujuk pada Marxist film theory tapi lebih kepada Scientific Realism (Salt 2009). Scientific Realism merujuk pada kondisi objek yang di dalamnya benar-benar terdapat sesuatu yang bisa diteliti (secara material/empirik), oleh sebab itu Salt selalu menggunakan material film sebagai objek penelitian. Untuk itu, hanya diperlukan satu syarat agar teorinya dapat tercapai, yaitu hasil penelitian yang dilakukan harus menghasilkan informasi baru yang pasti tentang style film dan tidak akan berubah untuk jangka waktu yang lama.

Barry Salt dalam teorinya menitikberatkan pada pentingnya menghormati kaidah-kaidah ilmiah/sains ke 
dalam kajian sinema. Sementara dalam penerapan teorinya, Salt memusatkan kajian analisisnya lebih kepada konvensi teknis-Eisenstein. Karena itu, banyak yang menganggap teori Salt ini mengembalikan tradisi Formalisme Eisentein, namun yang membedakannya adalah teori Salt memiliki persamaan ciri dengan teori-teori yang lahir pada masa Post-Structuralist di mana estetika dan efektivitas fenomenologi diabaikan untuk mengeksplorasi produksi makna teks sebagai aset strategi diskursif. Tetapi yang membedakannya dengan Post-Structuralist adalah tingkat validitas analisisnya (Bordwell and Thompson 2015).

Kritik Barry Salt terhadap teori-teori interpretasi film terfokus pada lemahnya persepsi atau interpretasi yang digunakan sebagai alat dalam menganalisa yang diragukan objektivitasnya. Dalam pendekatan ilmiah (Positivisme), interpretasi atau subjektivitas dalam penelitian, tidak memiliki bukti empirik yang dapat mendukung kebenaran hipotesisnya, sehingga hasil yang ditemukan hanyalah berupa asumsi-asumsi yang dapat sewaktu-waktu dibantahkan bahkan dimentahkan kembali. Setidaknya terdapat tiga kelemahan yang terdapat pada kajian sinema yang dilandasi interpretasi yaitu (Salt 2009) :

a) Subjektif dan tidak terukur.

b) Ketidakkonsistenan interpretasi. c) Tidak memiliki metode/rumusan yang pasti.

Barry Salt menyerukan pentingnya peneliti film untuk lebih mempertimbangkan aspek teknis ke dalam rumusan interpretasi filmnya untuk menghindari hal-hal di atas. Hal ini menurut Salt menjadi kekurangan yang menonjol di kalangan kritik akademis saat ini. Berpegangan pada aspek konstruktif dalam memformulasikan rumusan teori filmnya, Salt kemudian menggunakan metode analisis dan evaluatif yang seobjektif mungkin dalam menelaah lebih dalam tentang berbagai unsur dalam sinema. Metode analisis dipandang perlu demi menguji seberapa tinggi tingkat akurasi rumusan teori yang digunakan, demikian juga halnya dengan metode evaluatifnya.

Perhitungan style Salt menggunakan statistik yang difungsikan sebagai alat dalam menjumlah data kemudian merepresentasikan data tersebut sebagai aturan dasar yang bersifat tetap atau final. Dalam analisis style, statistik digunakan menganalisa atau lebih tepatnya mengukur style. Dengan memasukkan statistik sebagai alat analisanya, Salt berhasil menghindari hubungan style dan tema sebuah film dimana style dalam film lebih dipandang sekedar untuk kepentingan estetika semata. Stylometry secara spesifik memiliki tiga tujuan standar, yaitu (Salt 2009) : 
a) Menawarkan analisis style dengan menggunakan pendekatan positivisme /kuantiatif.

b) Menghindari sengketa teks.

c) Untuk mengidentifikasi kronologis film ketika adegan atau urutan komposisi tidak jelas atau tidak runut seperti dalam film-film montage.

Barry Salt menitikberatkan kajiannya pada kaidah ilmiah yang logis, rasional dan objektif. Meski dianggap melakukan dehumanisasi, menurut Salt kajian sinema tidaklah semudah sekedar menonton film lalu memindahkan pengalaman tersebut dengan dukungan teori-teori manipulatif. Pada penerapan Stylometry, Salt melibatkan metode statistik dengan tujuan utamanya adalah mengumpulkan jumlah dan frekuensi data parameter formal sutradara kemudian diwakilkan ke dalam grafik dan presentase variabel.

Statistik dikenal sebagai jembatan penghubung antara ilmu-ilmu sosial dengan penelitian kuantitatif (Positivisme). Statistik digunakan untuk mengukur fenomena-fenomena sosial ke dalam grafik-grafik angka untuk kemudian digeneralkan. Namun, dalam Stylometry sama sekali tidak ditujukan untuk pengamatan perilaku dan konstruksi sosial masyarakat. Pada penerapannya, Salt kembali pada tradisi Formalisme klasik, dimana objek penelitiannya terfokus pada material film itu sendiri. Penggunaan statistik dalam Stylometry setidaknya memiliki manfaat secara khusus dalam kajian sinema antara lain :

a) Stylometry digunakan untuk mengukur reliabilitas atau konsistensi style sebuah film maupun style seorang sutradara.

b) Stylometry sebagai alat pembanding dua atau lebih style film.

\section{METODE}

Teori Praksis yang dimaksud dalam Stylometry adalah penerapan sebuah metode ke dalam bentuk kongkrit yang diawali dari memilah sampel, mengkonstruksinya menjadi sebuah data, menganalisa, lalu mengevaluasi data. Hal ini bertujuan agar hasil analisis data yang didapatkan adalah hasil yang akurat, teruji dan sistematis. Barry Salt menilai bahwa melalui suatu konstruksi pola yang terukur, style seorang sutradara dapat terdeteksi melalui parameter formal yang diterapkan ke dalam filmnya. la merepresentasekan parameter formal tersebut ke dalam grafik batang dan persentase. Parameter formal yang dimaksud adalah wilayah kerja dari sutradara yang bisa diuji secara empiris.

Film style adalah objek yang paling empiris dalam film dan shot adalah parameternya (Eisenstein 1957). Maka elemen shot inilah yang kemudian diolah menjadi data mentah oleh Salt dengan mengkonstruksi data-data ini ke dalam bentuk diagram, grafik, dan persentase. Dari hasil pembacaan atas parameter 
tersebut bisa memberikan gambaran tentang style seorang sutradara (Barry Salt 1992 : 27). Adapun elemen shot yang akan diolah adalah sebagai berikut (Barry Salt $1992: 158)$ :

a. Panjang Shot Rata-Rata (Average Shot Length/ASL)

Konsep Averege Shot Length (ASL) merupakan panjang dari film dibagi dengan jumlah shot di dalam film, yang dapat dinyatakan sebagai panjang fisik yang sebenarnya dari film atau lebih dikenal sebagai durasi. Sebelumnya, film yang menggunakan bahan baku celluloid dan film bisu, menggunakan satuan feet yang diambil dari panjang pita celluloid, namun hal ini menimbulkan persoalan di mana kecepatan proyektor film mempengaruhi durasi film. Untuk itu, Salt mengganti satuan ASL menjadi detik, ketika perbandingan dilakukan dengan filmfilm yang dibuat pada masa yang berbeda atau format yang berbeda seperti format video ataupun digital.

Barry Salt merekomendasikan beberapa cara untuk memilih interval waktu yang digunakan dalam menghitung ASL, yaitu :

a) Gunakan interval waktu per satu menit atau 60 detik pada film dalam cakram digital (CD) atau 100-feet pada film $35 \mathrm{~mm}$.

b) Lakukan perhitungan jumlah tipe shot dalam angka (misalnya 50 tipe shot) kemudian hitunglah jumlah shot dari keseluruhan tipe shot yang ada.

c) ASL atau panjang rata-rata shot didapat dari perhitungan interval waktu keseluruhan scene dalam film. Kemudian hitunglah jumlah shot seluruhnya. Jika scene berlangsung 2 menit (120 detik) dan jumlah shot setiap scene adalah 12 maka ASLnya adalah 10 detik.

Secara sederhana ASL didapatkan melalui rumus berikut :

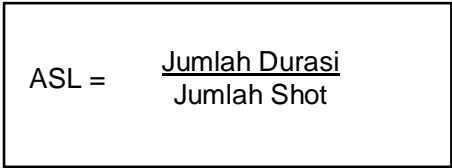

b. Shot Scale atau Type of Shot

Shot Scale merupakan ukuran besar kecilnya sebuah objek yang ditangkap oleh kamera untuk kemudian diproyeksikan. Istilah lain disebut dengan nama tipe shot. Di dalam skala shot terdapat tujuh varibel yang menunjukkan parameter formal. Variabel-variabel tersebut adalah Big Close Up (BCU), Close Up (CU), Medium Close Up (MCU), Medium Shot (MS), Medium Long Shot (MLS), Full Shot (FS), Long Shot (LS). Acuan dalam menetapkan skala yang digunakan dapat dilihat pada Gambar 1.

Barry Salt pada awalnya mendapatkan skala shot kebanyakan dari data-data untuk ASL (scene dan jumlah shot) dan hasil persentase terbalik dari potongan angle yang diambil dari 30 menit 
panjang film atau setidaknya 200 shot. Namun kriteria tersebut tidak memuaskan dengan range error mencapai lebih 10\%, karenanya distribusi skala shot sekarang diambil dari keseluruhan panjang film.

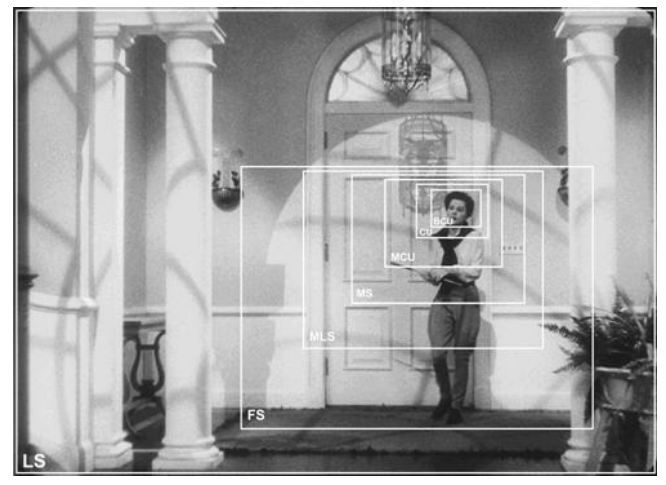

Gambar 1. Perbedaan skala shot - long shot (LS), full shot (FS), medium long shot (MLS), medium shot (MS), medium close up (MCU), close up (CU), dan big close up (BCU)

Perhitungan persentase skala shot didapatkan dengan membagi jumlah skala shot dengan jumlah shot seperti rumus di bawah ini, dengan tujuan melakukan generalisir terhadap hasil perhitungan skala shot.

\section{Jumlah skala shot Jumlah shot}

\section{c. Camera Work-Movement}

Tren penggunaan gerak kamera muncul pada penghujung era film bisu hingga memasuki periode film bersuara. Hal ini memunculkan perbedaan antara jumlah shot dengan gerak kamera (camera movement). Perdebatan pun muncul tentang apakah gerak kamera merupakan salah satu bagian dari style sutradara, di mana gerak kamera tidak menampakkan kerja-kerja sutradara melainkan kerja cameraman. Namun, menyadari bahwa gerak kamera berada dalam kewenangan sutradara, dalam hal ini kamera bergerak sesuai keinginan sutradara, maka bahwa camera movement merupakan bagian dari style sutradara.

Secara teknis Camera Work terbagi atas diam (still) dan bergerak (movement). Camera movement memiliki beberapa sub teknis dasar yaitu pan, tilt, track, hand held, crane, dan zoom. Penggunaan parameter ini untuk memudahkan identifikasi hal hal yang berkaitan dengan perangkat kerja kamera, yang nantinya akan dihitung dan dikakulasikan ke dalam bentuk persentase ataupun grafik batang.

Teknik pengumpulan data dalam kajian film-film Chaerul Umam ini menggunakan teknik Purposive Sampling. Penerapan stylometry dalam analisis film style kali ini menggunakan 4 film karya Chaerul Umam berdasarkan periode produksinya. Sebelum sampel dianalisa, pertama-tama yang dilakukan adalah mengumpulkan data film-film karya Chaerul Umam. Untuk memudahkan pengambilan sampel, data yang terkumpul kemudian dibagi sesuai periode produksi dan temanya.

Tabel 2 : Daftar film Chaerul Umam

\begin{tabular}{|c|c|l|}
\hline Genre & Periode & \multicolumn{1}{c|}{ Judul Film } \\
\hline \multirow{2}{*}{} & 1970 & $\begin{array}{l}\text { Cinta Putih (1977) } \\
\text { Sepasang Merpati (1979) }\end{array}$ \\
\cline { 2 - 3 } & 1980 & Betapa Damai Hati Kami \\
\hline
\end{tabular}




\section{CAPTURE}

\begin{tabular}{|c|c|c|}
\hline \multirow[t]{3}{*}{ Drama } & & $\begin{array}{l}(1981) \\
\text { Gadis Marathon (1981) } \\
\text { Hati yang Perawan (1984) } \\
\text { Bintang Kejora (1986) } \\
\text { Terang Bulan di Tengah } \\
\text { Hari (1988) } \\
\text { Malioboro (1989) }\end{array}$ \\
\hline & 1990 & Boss Carmad (1990) \\
\hline & 2000 & - \\
\hline \multirow{4}{*}{ Komedi } & 1970 & Tiga Sekawan (1975) \\
\hline & 1980 & $\begin{array}{l}\text { Kejarlah Daku Kau } \\
\text { Kutangkap (1985) } \\
\text { Sama Juga Bohong (1986) } \\
\text { Joe Turun ke Desa (1989), }\end{array}$ \\
\hline & 1990 & $\begin{array}{l}\text { Jangan Bilang Siapa-siapa } \\
\text { (1990) } \\
\text { Om Pasikom (1990) } \\
\text { Ramadhan dan Ramona } \\
(1992)\end{array}$ \\
\hline & 2000 & - \\
\hline \multirow{4}{*}{ Religi } & 1970 & Al Kautsar (1977) \\
\hline & 1980 & $\begin{array}{l}\text { Titian Serambut Dibelah } \\
\text { Tujuh (1982), }\end{array}$ \\
\hline & 1990 & $\begin{array}{l}\text { Nada dan Dakwah (1991) } \\
\text { Fatahillah (1997) }\end{array}$ \\
\hline & 2000 & $\begin{array}{l}\text { Ketika Cinta Bertasbih } \\
(2009) \\
\text { Ketika Cinta Bertasbih } \\
(2010) \\
\text { Cinta Suci Zahrana (2012) }\end{array}$ \\
\hline
\end{tabular}

Tabel di atas menunjukkan bahwa selama empat dekade karir tema religi konsisten diproduksi oleh sutradara Chaerul Umam. Dari film-film bertema religi tersebut diambil satu sampel untuk setiap dekade, maka sampel yang diperoleh dapat dilihat dalam tabel 3 .

Tabel 3. Sampel film religi Chaerul Umam

\begin{tabular}{|c|l|}
\hline Periode & \multicolumn{1}{|c|}{ Judul Film } \\
\hline 1970 & Al Kautsar \\
1980 & Titian Serambut Dibelah Tujuh \\
1990 & Nada dan Dakwah \\
2000 & Ketika Cinta Bertasbih \\
\hline
\end{tabular}

Keempat film sampel tersebut yang diobservasi dan dianalisis dengan pendekatan Stylometry.

\section{PEMBAHASAN}

\subsection{Aplikasi Stylometry dalam Analisis} Film Style

\section{a. Panjang Shot Rata-Rata (Average Shot Length/ASL)}

Hasil perhitungan terhadap jumlah shot dan durasi film dari keempat film Chaerul Umam dapat dilihat pada tabel di bawah.

Tabel 4. Hasil perhitungan ASL film sampel

\begin{tabular}{|c|c|c|c|}
\hline Judul & $\begin{array}{l}\text { Durasi } \\
\text { (detik) }\end{array}$ & $\begin{array}{c}\text { Jumlah } \\
\text { shot }\end{array}$ & ASL \\
\hline Al Kautsar & $\begin{array}{c}97 \text { menit } \\
\text { (5.820 dtk) }\end{array}$ & 779 shot & $\begin{array}{c}7,4 \\
\text { dtk/shot }\end{array}$ \\
\hline $\begin{array}{l}\text { Titian } \\
\text { Serambut } \\
\text { Dibelah } \\
\text { Tujuh }\end{array}$ & $\begin{array}{l}90 \text { menit } \\
\text { (5.400 dtk) }\end{array}$ & 822 shot & $\begin{array}{c}6,5 \\
\mathrm{dtk} / \text { shot }\end{array}$ \\
\hline $\begin{array}{l}\text { Nada dan } \\
\text { Dakwah }\end{array}$ & $\begin{array}{l}90 \text { menit } \\
(5.400 \mathrm{dtk})\end{array}$ & 732 shot & $\begin{array}{c}7,3 \\
\text { dtk/shot }\end{array}$ \\
\hline $\begin{array}{l}\text { Ketika Cita } \\
\text { Bertasbih I }\end{array}$ & $\begin{array}{l}115 \text { menit } \\
(6.900 \mathrm{dtk})\end{array}$ & $\begin{array}{l}1.290 \\
\text { shot }\end{array}$ & $\begin{array}{c}5,3 \\
\mathrm{dtk} / \text { shot }\end{array}$ \\
\hline
\end{tabular}

Hasil di atas menunjukkan film Ketika Cinta Bertasbihl yang memiliki durasi dan jumlah shot terbesar dengan ASL terkecil, sementara film Al Kautsar dan Nada dan Dakwah memiliki jumlah shot 700-an dengan ASL-nya hanya berbeda 0,1 detik. Ini membuktikan bahwa jumlah shot film berbanding terbalik dengan besar ASL. Dengan kata lain semakin banyak jumlah shot suatu film maka akan semakin kecil ASL yang didapatkan. 


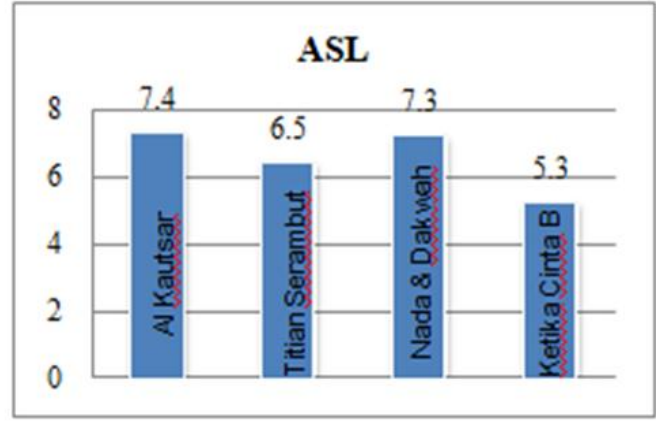

Gambar 2. Grafik film Chaerul Umam

Nilai ASL keempat film tersebut tergolong rendah. Barry Salt membagi nilai ASL ke dalam dua kategori, ASL dengan jumlah 1,0-9,0 detik/shot masuk kategori ASL kecil, sementara ASL 9,1 dtk/shot ke atas masuk pada kategori nilai ASL besar. Hal ini menunjukkan bahwa semakin tinggi jumlah shot maka semakin rendah nilai ASL, artinya semakin cepat pula perpindahan antara satu shot ke shot yang lainnya. Film Ketika Cinta Bertasbih I (jumlah shot tertinggi) perpindahan gambarnya lebih dinamis jika dikomparasi dengan Nada dan Dakwah (jumlah shot terendah).

Penurunan 2 detik menunjukkan bahwa film Chaerul Umam menggunakan peralihan shot lebih cepat dibanding era 90-an. Meskipun ada penurunan 2 detik/shot, nilai ASL dari style Chaerul Umam masih tergolong stabil. Hasil ASL menunjukkan film Chaerul Umam menggunakan shot-shot pendek. Dengan kata lain perpindahan dari shot satu ke shot yang lain semakin cepat, ini menimbulkan efek yang lebih dinamis. Faktor teknologi kamera yang berkembang menjadikan bahasa visual lebih variatif bisa menjadi salah satu faktor. Pendapat ini tentunya membutuhkan kajian lebih lanjut.

\section{b. Skala Shot}

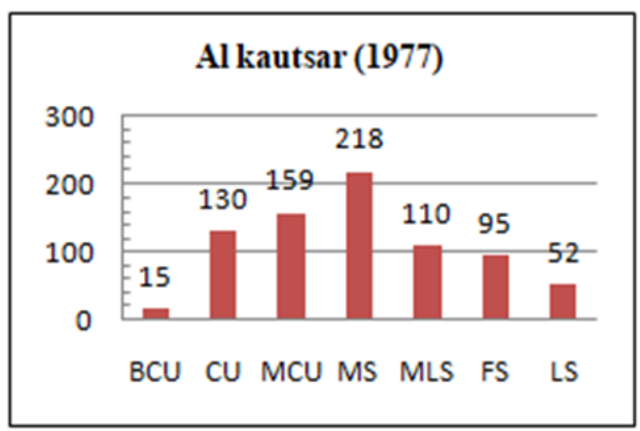

Gambar 3. Grafik skala shot film Al Kautsar (1977)

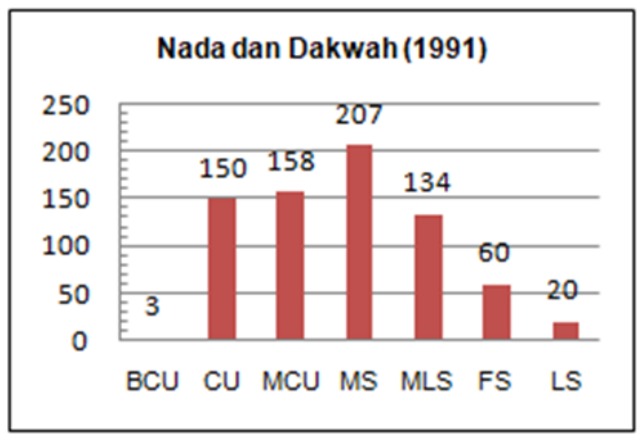

Gambar 4. Grafik skala shot film Nada dan Dakwah (1991)

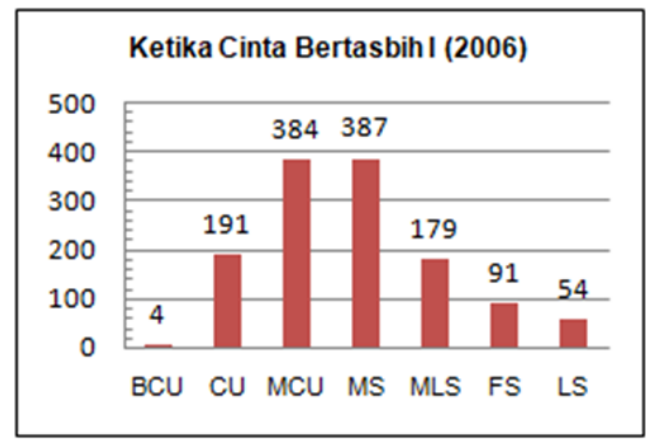

Gambar 5. Grafik skala shot film Ketika Cinta Bertasbih (2006)

Setelah dilakukan perhitungan terhadap seluruh skala shot dalam film-film sampel, didapatkan data yang tampak 


\section{CAPTURE}

pada Gambar 3, 4, dan 5 di atas.

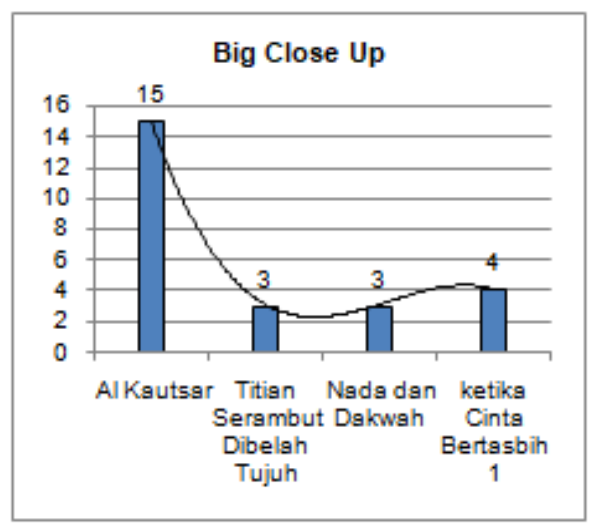

Gambar 6. Grafik perbandingan skala shot BCU film karya Chaerul Umam

Hasil perhitungan skala shot di atas memperlihatkan bahwa style Chaerul Umam sangat fluktuatif. Perbedaan menonjolnya adalah evolusi penggunaan big close up secara grafik menurun, sedangkan medium long shot memperlihatkan grafik menanjak. Bisa jadi, hal ini berpengaruh pada durasi masing masing film. Dari data itu dapat dikatakan bahwa faktor durasi mempengaruhi jumlah shot, semakin banyak durasi semakin banyak shot. Perbandingan skala shot filmfilm Chaerul Umam dapat dilihat melalui grafik skala shot pada Gambar 6 di atas.

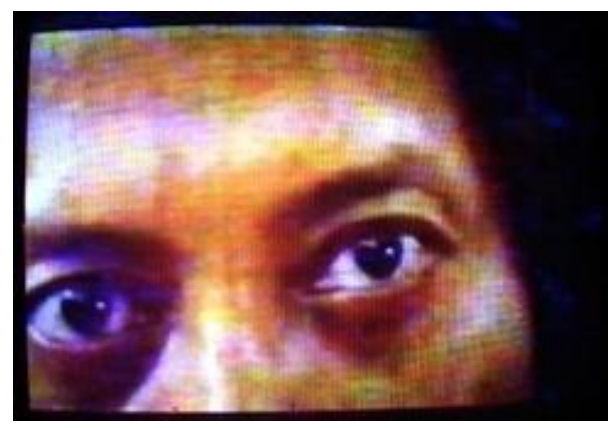

Gambar 7. Contoh penggunaan BCU film Al Kautsar

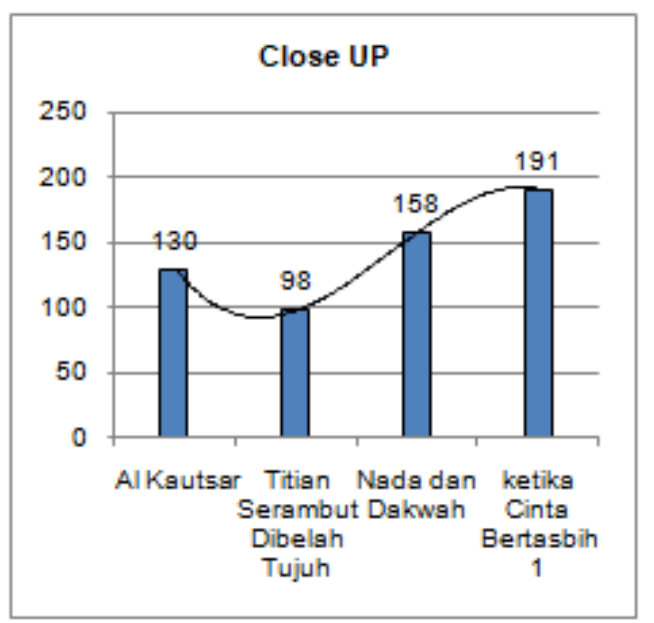

Gambar 8. Grafik perbandingan skala shot CU film karya Chaerul Umam

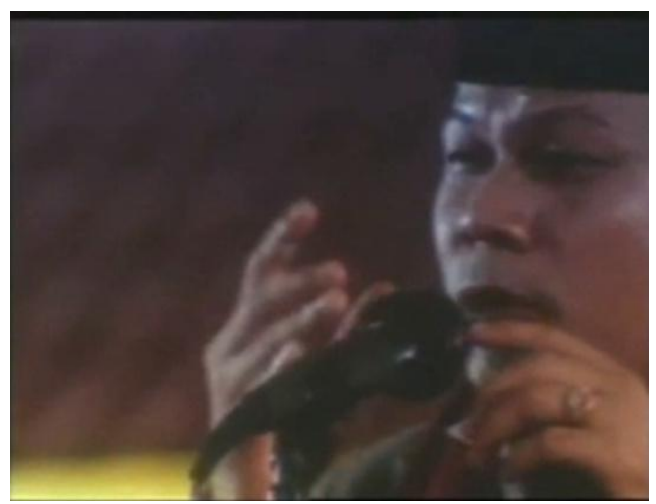

Gambar 9. Skala CU dalam film Nada dan Dakwah

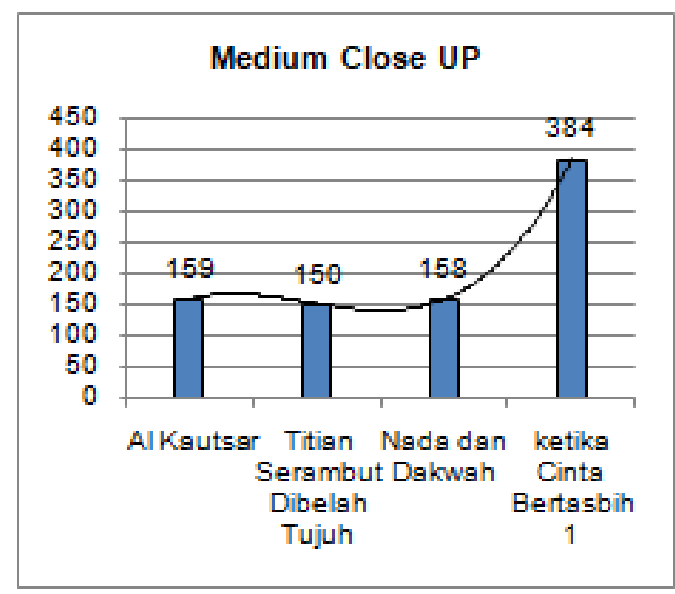

Gambar 10. Grafik perbandingan skala shot MCU film karya Chaerul Umam 


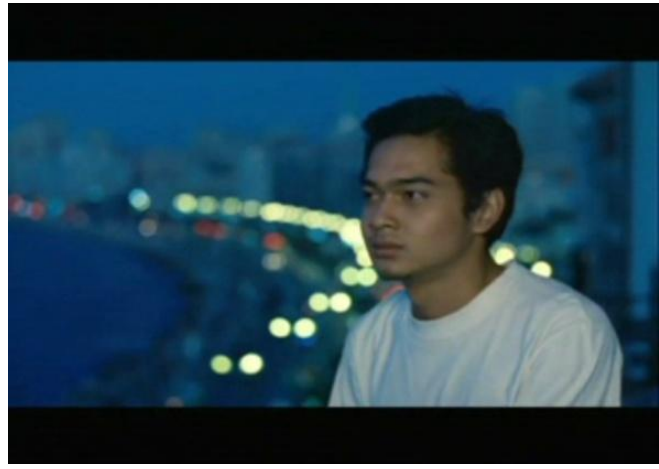

Gambar 11. Penggunaan skala shot MCU dalam film Ketika Cinta Bertasbih I

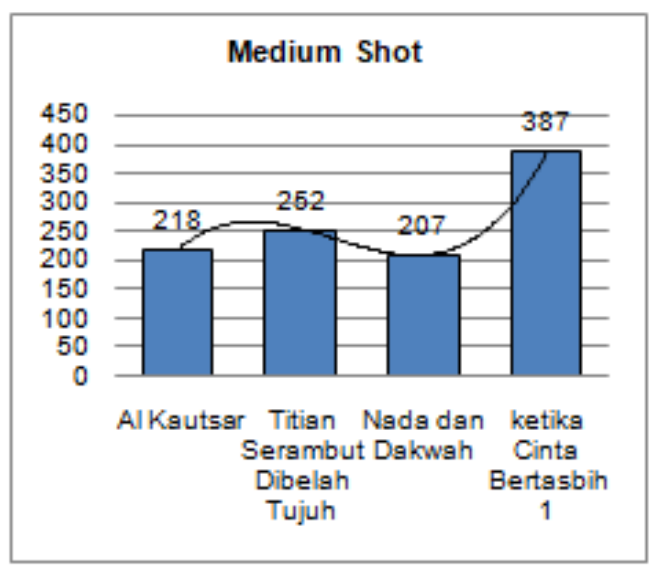

Gambar 12. Grafik perbandingan skala shot MS film karya Chaerul Umam

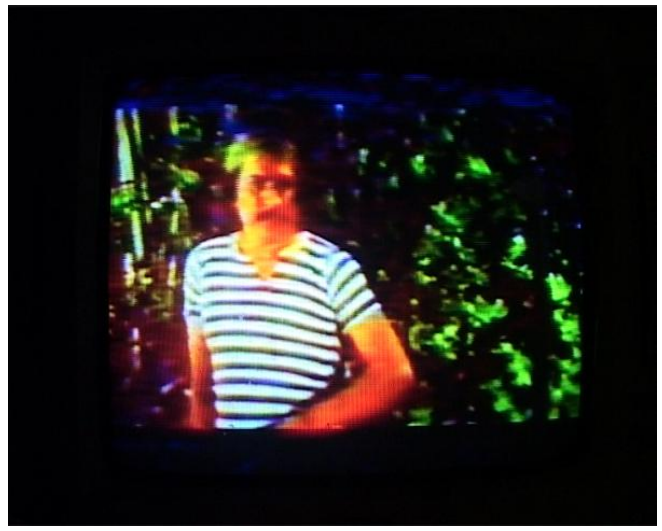

Gambar 13. Penggunaan skala shot MS film Al Kautsar

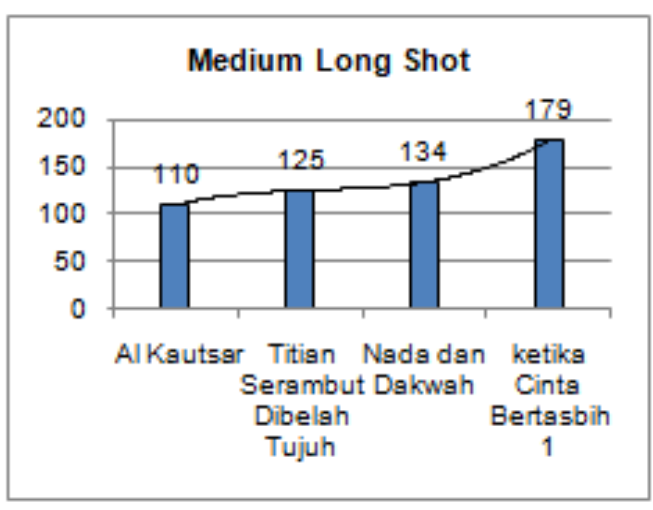

Gambar 14. Grafik perbandingan skala shot MLS film karya Chaerul Umam

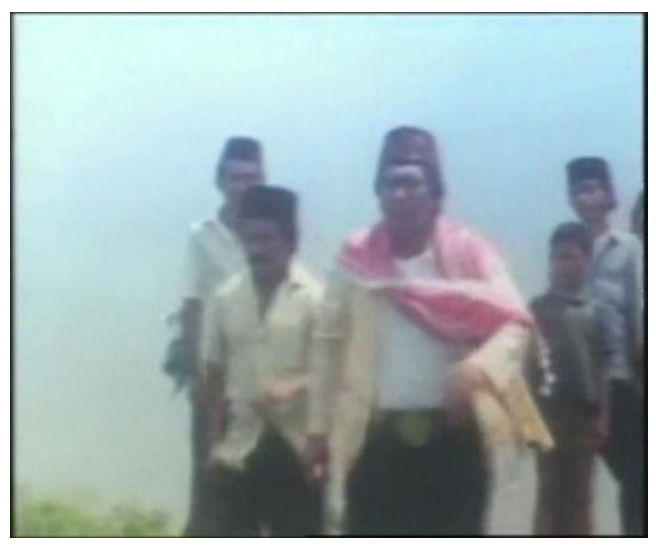

Gambar 14. Penggunaan MLS film Nada dan Dakwah

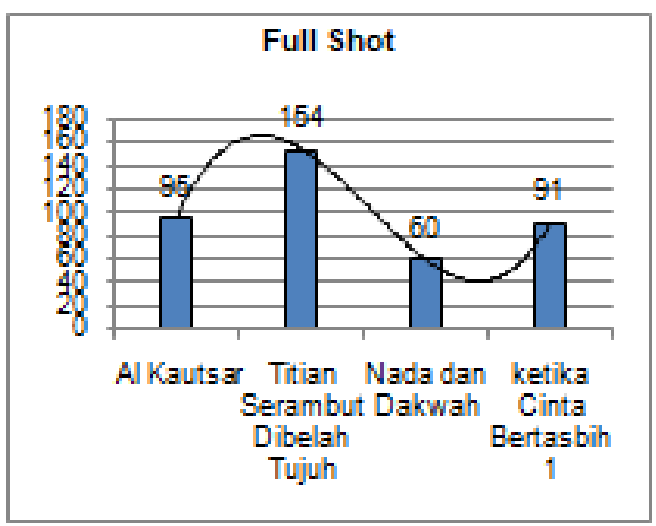

Gambar 15. Grafik perbandingan skala shot FS film karya Chaerul Umam 


\section{CAPTURE}

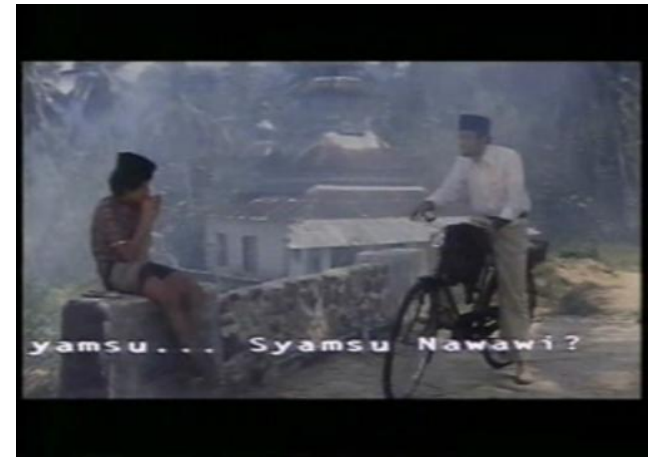

Gambar 16. Pengunaan FS dalam film Titian Serambut Dibelah Tujuh

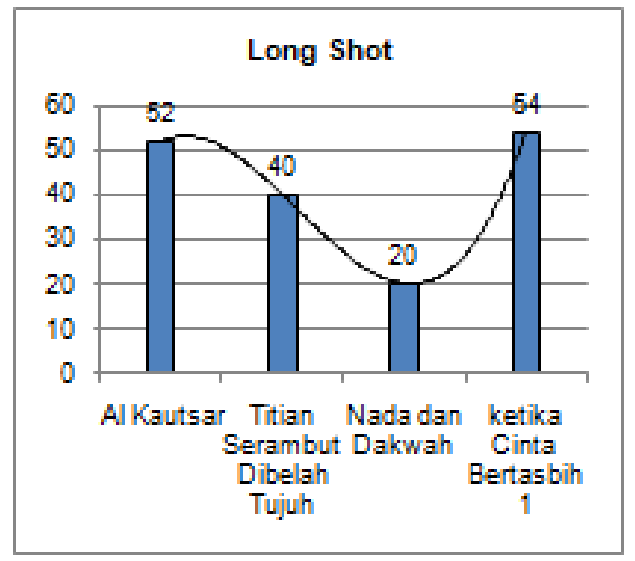

Gambar 17. Grafik perbandingan skala shot LS karya Chaerul Umam

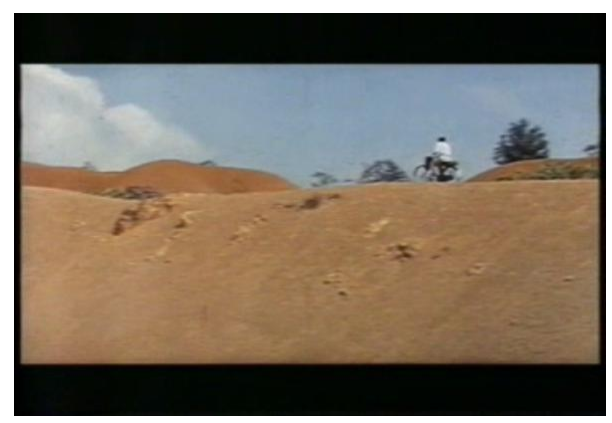

Gambar 18. Pengunaan skala shot LS dalam film Titian Serambut Dibelah Tujuh

Hasil perhitungan skala shot menunjukkan bahwa style Chaerul Umam sangat fluktuatif. Perbedaannya yang tampak menonjol adalah penggunaan big close up secara grafik menurun, sedangkan medium long shot memperlihatkan grafik menanjak. Hal ini dapat disimpulkan sementara bahwa faktor durasi mempengaruhi jumlah shot, semakin banyak durasi semakin banyak shot

$$
\text { Jumlah waktu (durasi) yang }
$$

digunakan juga akan membuat lebih banyak ruang untuk mengekplorasi komposisi. Oleh karena itu, sebaiknya perhitungan persentase skala shot dilakukan dengan membagi skala shot dengan jumlah shot yang ada. Tujuannya adalah melakukan generalisir terhadap hasil perhitungan skala shot, adapun hasil perhitungan persentase dapat dilihat melalui diagram berikut:

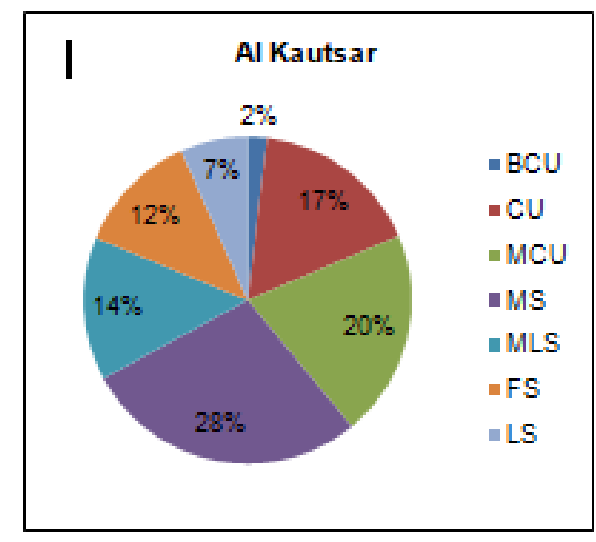

Gambar 19. Persentase skala shot film Al Kautsar

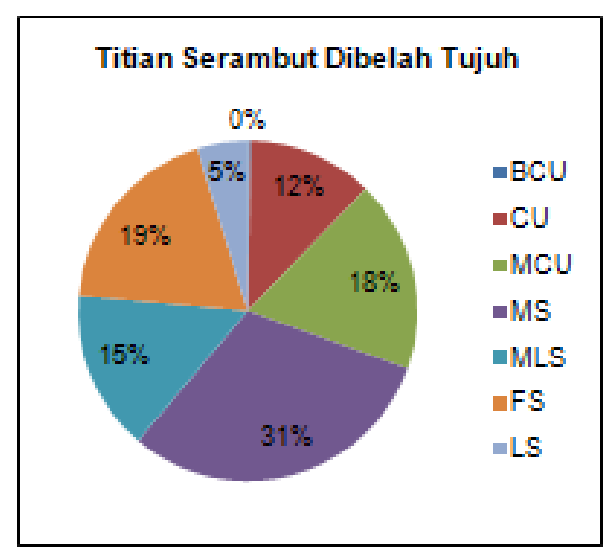

Gambar 20. Persentase skala shot film Titian Serambut Dibelah Tujuh 


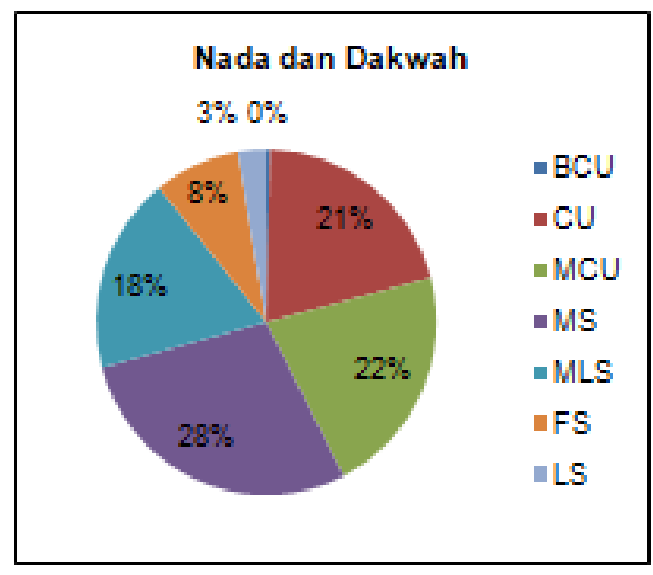

Gambar 21. Persentase skala shot film Nada dan Dakwah

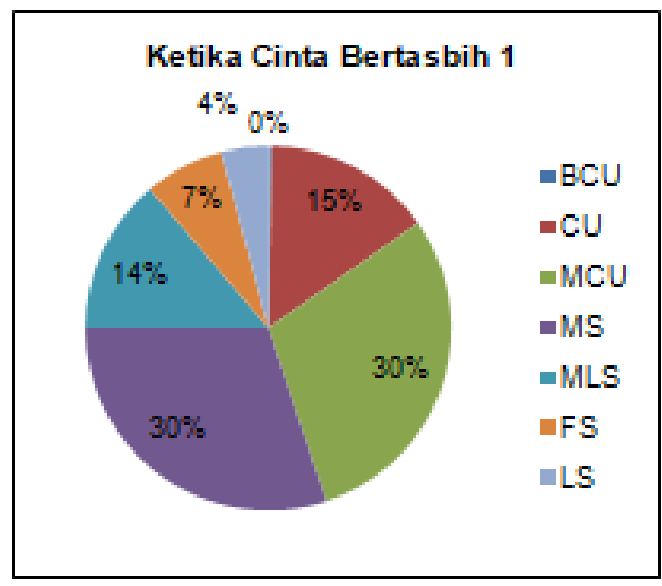

Gambar 22. Persentase skala shot film Ketika Cinta Bertasbih I

teknis dasar yaitu pan, tilt, track, hand held, crane, dan zoom. Penggunaan parameter ini untuk memudahkan identifikasi hal-hal yang berkaitan dengan perangkat kerja kamera.

Observasi terhadap kamera statis lebih mudah dilakukan dibanding dengan observasi camera movement. Pengamatan camera movement diperlukan pengetahuan teknis tentang kerja kamera serta kepekaan dalam menentukan teknik kamera saat menampilkan gambar..
Hasil skala shot setelah dimasukkan durasi film sebagai faktor penentu penggunaan ke dalam bentuk persentase, tampak style Chaerul Umam tidak mengalami perubahan yang signifikan, persentase skala shot yang digunakan dari yang terbesar hingga yang terkecil tampak sama. Ini membuktikan bahwa style Chaerul Umam cenderung stabil, tampak pada skala shot filmnya dari tahun 1970-an hingga 2000-an.

\section{c. Pergerakan Kamera (Camera Work)}

Di dalam kajian sinema, Camera Work berarti pergerakan dari kamera, baik berupa gerak body kamera maupun perubahan nilai sudut lensa (zoom). Camera work tidak berbicara tentang bagaimana mekanisme kamera membentuk gambar.

Camera work secara teknis terbagi atas still (diam) dan movement (gerak). Camera movement memiliki beberapa sub

Setelah melakukan perhitungan pada camera work terhadap film karya Chaerul Umam, didapatkan hasil yang dapat dilihat pada tabel berikut :

Tabel 4. Hasil perhitungan camera movement film-film Chaerul Umam (dalam skala shot)

\begin{tabular}{|c|c|c|c|c|c|c|c|}
\hline Judul & Pan & Tilt & Zoom & Track & $\begin{array}{c}\text { Hand } \\
\text { Held }\end{array}$ & $\begin{array}{c}\text { Cran } \\
\mathrm{e}\end{array}$ & $\Sigma$ \\
\hline AK & 140 & 54 & 50 & 21 & 2 & - & 265 \\
\hline TSDT & 137 & 72 & 13 & 36 & 1 & - & 259 \\
\hline NdD & 152 & 30 & 64 & 12 & - & - & 258 \\
\hline KCT-I & 186 & 46 & 1 & 68 & 5 & 8 & 314 \\
\hline $\begin{array}{c}\text { Rata- } \\
\text { rata }\end{array}$ & 154 & 51 & 42 & 35 & 2 & 2 & 274 \\
\hline
\end{tabular}

Hasil perhitungan camera movement 


\section{CAPTURE}

terbesar tampak pada film Ketika Cinta Bertasbih I dengan jumlah 314 shot. Ditemukan juga bahwa teknik crane digunakan pada periode 2000-an. Untuk lebih jelas hasil perhitungan camera movement dapat dilihat melalui diagram berikut:

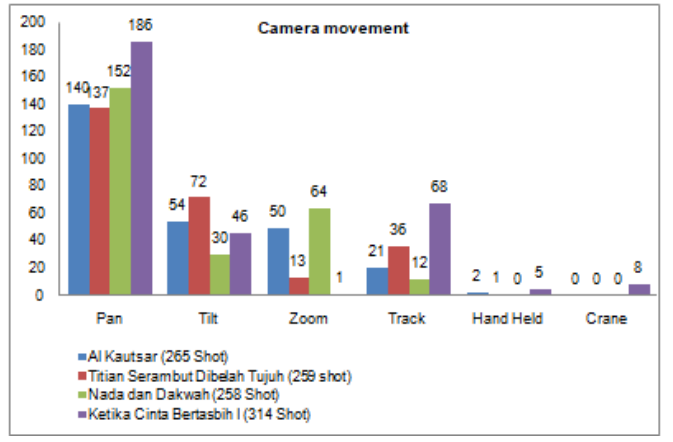

Gambar 23. Perbandingan camera movement dalam film-film karya Chaerul Umam

Film-film karya Chaerul Umam periode 2000-an juga ditandai dengan perubahan zoom yang cukup signifikan. Periode sebelumnya (1970-an hingga 1990-an), zoom cukup banyak digunakan, sekitar 10-60 shot, namun periode 2000-an zoom hanya digunakan 1 shot. Sedangkan penggunaan teknik pan, kamera bergerak secara vertikal menjadi teknik 'favorit' Chaerul Umam, hal ini terlihat dari dominasi pan dalam film-filmnya selama empat dekade.

Teknik zoom sangat popular dalam teknik kamera di era 90-an, namun penggunaannya berkurang di penghujung 1990-an. Tampak ada indikasi bahwa perkembangan teknologi pendukung kamera berpengaruh besar padanya.
Penggunaan zoom dan crane paling jelas terlihat pada film-film karya Chaerul Umam.

Penggunaan teknik crane merupakan hal baru dalam film Chaerul yang menggantikan popularitas zoom sebelumnya. Ketika penggunaan zoom mulai meredup, teknik crane mulai terlihat. Indikasi bahwa Chaerul Umam memanfaatkan teknologi pendukung kamera sebagai estetika baru dalam filmnya terlihat di era 2000-an. Ketika teknik zoom banyak digunakan, maka teknik track berkurang, begitupun sebaliknya.

Pola yang terlihat pada teknik zoom dan track cukup menarik. Upaya Chaerul Umam untuk 'mengkonversi' zoom ke teknik track sulit dibedakan secara visual, mengingat pendekatan teknik ini sangat sulit dideteksi oleh penonton awam, karena memiliki estetika tersendiri di mana secara visual penggunaan teknik ini sangat mirip. Indikasi ini pula yang memperlihatkan bahwa teknik zoom yang begitu popular saat itu, mulai tergoyahkan dengan berkembangnya penggunaan camera tracking di industri film nasional.

\section{Perbandingan antara camera} movement dengan kamera statis terlihat jumlah kamera statis lebih besar, tampak pada grafik di bawah ini. 


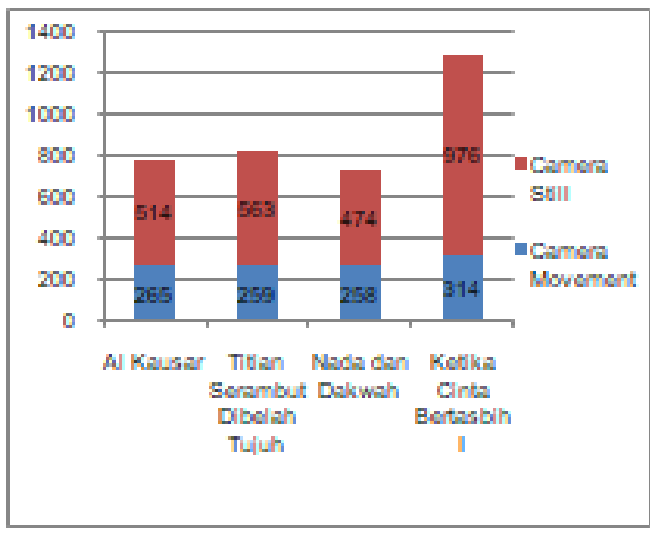

Gambar 24. Perbandingan camera movement dan kamera statis dalam film-film karya Chaerul Umam

Persentase perbandingan antara camera still dan camera movement pada masing-masing film dapat dilihat melalui grafik berikut:

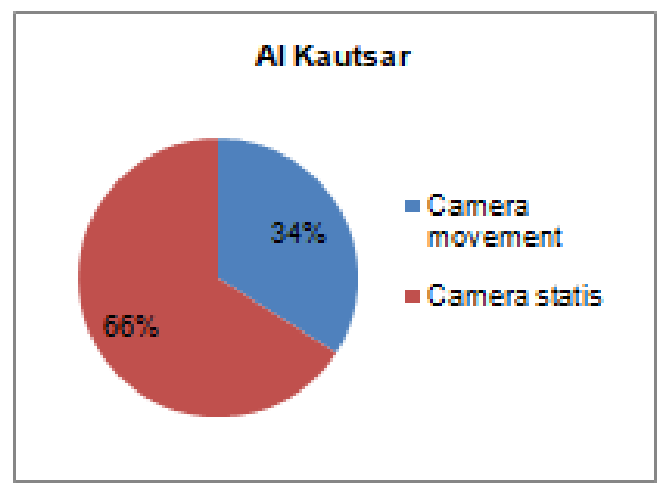

Gambar 25. Persentase camera work dalam film Al Kautsar

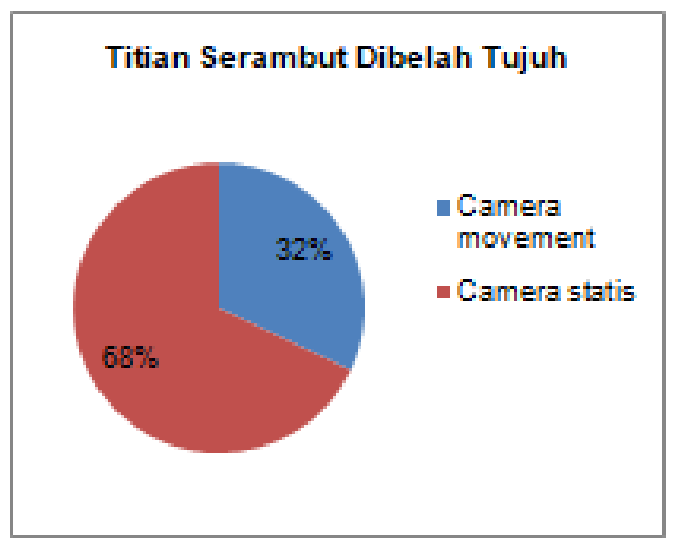

Gambar 26. Persentase camera work dalam film Titian Serambut Dibelah Tujuh

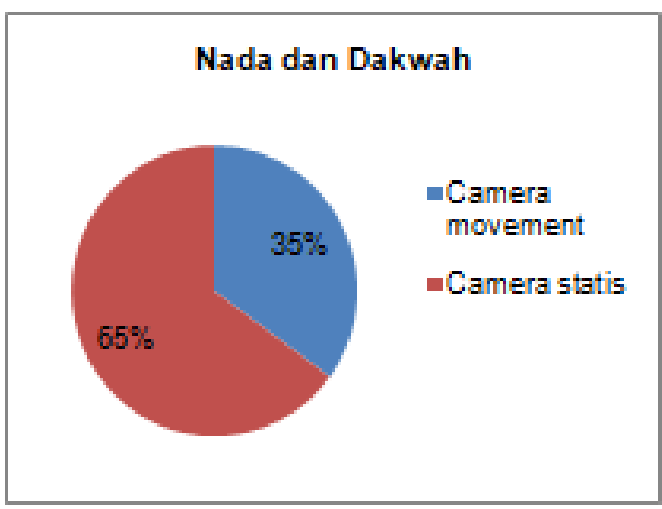

Gambar 27. Persentase camera work dalam film Nada dan Dakwah

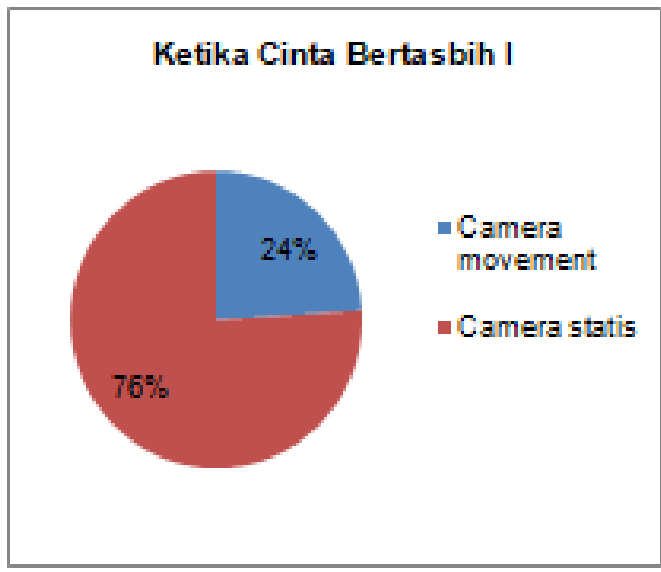

Gambar 27. Persentase camera work dalam film Ketika Cinta Bertasbih I

Persentase di atas memperlihatkan bahwa teknik camera movement di era 2000-an mengalami penurunan dibanding era sebelumnya yang masih berkisar di atas $30 \%$. Teknik movement dalam film Ketika Cinta Bertasbih bahkan mengalami penurunan hingga $11 \%$ dari film sebelumnya. Dari seluruh adegan film, penonton hanya diberikan $1 / 4$ adegan yang dinamis, dan $3 / 4$ lainnnya adalah statis.

Patut dikaji lebih lanjut mengingat teknologi yang berkembang di era 2000-an memungkinkan untuk menyajikan tampilan 


\section{CAPTURE}

visual yang lebih kaya. Ataukah mungkin Chareul Umam mencoba untuk tidak terpengaruh dan justru menjauhi kekayaan visual dalam teknik kamera yang begitu berkembang ke dalam film Ketika Cinta Bertasbih, mengingat film ini diproduksi oleh perusahaan film yang besar dan hasil adaptasi dari novel best seller.

Hasil perhitungan (lihat Tabel 1) camera movement terbesar ada pada film Ketika Cinta Bertasbih dengan jumlah 314 shot, namun dengan durasi 115 menit. Film ini memiliki nilai persentase paling kecil yakni $24 \%$ dibanding dengan film-film sebelumnya. Grafik di atas tampak bahwa film-film Chaerul Umam merupakan film dengan teknik kamera still, di mana persentase terbesar penggunaan teknik camera movement hanya berkisar pada $24 \%$ sampai dengan $35 \%$, selebihnya terlihat adegan-adegan kamera statis.

\subsection{Evaluasi Style Film Chaerul Umam}

Langkah selanjutnya dalam penerapan Stylometry adalah evaluasi lebih lanjut terhadap hasil analisis tersebut. Berikut ini temuan mengenai style film Chaerul Umam:

a. Evaluasi style ASL (Avarege Shot Length)

a) Keempat film Chaerul Umam tergolong dalam satuan ASL kecil di bawah 9 detik/shot.

b) Film Ketika Cinta Bertasbih I cenderung lebih dinamis dalam penggunaan shot. c) Meskipun ada penurunan $2 \mathrm{detik} / \mathrm{shot}$, nilaii ASL dari style Chaerul Umam masih tergolong stabil. Penurunan 2 detik menunjukkan film Chaerul Umam tahun 2000-an menggunakan shot-shot pendek, perpindahan dari shot satu ke shot yang lain semakin cepat dan lebih dinamis dari film sebelumnya.

\section{b. Evaluasi style skala shot}

a) Setelah film Al-kautsar Penggunaan Big Close Up (BCU) turun drastis hingga $80 \%$ dengan perbandingan sebagai berikut:

\begin{tabular}{|l|c|c|}
\hline \multicolumn{3}{|c|}{ Big Close Up (BCU) } \\
\hline Al Kautsar & 15 shot & $2 \%$ \\
\hline $\begin{array}{l}\text { Nada dan Dakwah } \\
\begin{array}{l}\text { Titian Serambut } \\
\text { Dibelah Tujuh } \\
\text { Ketika Cinta } \\
\text { Bertasbih I }\end{array}\end{array}$ & 3 shot & $0,4 \%$ \\
\hline
\end{tabular}

b) Penggunaan shot Close Up (CU) terbesar ada pada film Ketika Cinta Bertasbih I (190 shot). Hal ini tidak relevan dengan persentasenya (perhitungan shot dan durasi). Film Nada dan Dakwah posisinya teratas dalam penggunaan CU. Film Ketika Cinta Bertasbih I di posisi ketiga.

\begin{tabular}{|c|c|c|}
\hline \multicolumn{3}{|c|}{ Close Up (CU) } \\
\hline Al Kautsar & 130 shot & $16,6 \%$ \\
\hline Nada dan Dakwah & 150 shot & $20,4 \%$ \\
\hline $\begin{array}{l}\text { Titian Serambut } \\
\text { Dibelah Tujuh }\end{array}$ & 98 shot & $12 \%$ \\
\hline $\begin{array}{l}\text { Ketika Cinta } \\
\text { Bertasbih I }\end{array}$ & 191 shot & $14,8 \%$ \\
\hline
\end{tabular}


c) Dominasi tipe shot MCU tampak pada film Ketika Cinta Bertasbih I dengan 384 shot. Hal ini relevan dengan hasil persentasenya.

\begin{tabular}{|c|c|c|}
\hline \multicolumn{3}{|c|}{ Medium Close Up (MCU) } \\
\hline Al Kautsar & 159 shot & $20,5 \%$ \\
\hline Nada dan Dakwah & 158 shot & $21,5 \%$ \\
\hline $\begin{array}{l}\text { Titian Serambut } \\
\text { Dibelah Tujuh }\end{array}$ & 150 shot & $18,2 \%$ \\
\hline $\begin{array}{l}\text { Ketika Cinta } \\
\text { Bertasbih I }\end{array}$ & 384 shot & $29,7 \%$ \\
\hline
\end{tabular}

d) Medium Shot (MS) merupakan skala shot terpavorit dari masing masing film, bahwa secara persentase, lebih kurang $30 \%$ keseluruhan film mengutamakan skala shot ini (MS).

\begin{tabular}{|l|l|l|}
\hline \multicolumn{3}{|c|}{ Medium Shot (MS) } \\
\hline $\begin{array}{l}\text { Al Kautsar } \\
\text { Nada dan Dakwah }\end{array}$ & 218 shot & $28 \%$ \\
$\begin{array}{l}\text { Titian Serambut } \\
\text { Dibelah Tujuh } \\
\text { Ketika Cinta } \\
\text { Bertasbih I }\end{array}$ & 252 shot & $30,6 \%$ \\
\hline
\end{tabular}

e) Perhitungan tipe CU memperlihatkan jumlah shot justru berbanding terbalik dengan persentase durasi film. Skala medium long shot (MLS) film Ketika Cinta Bertasbih I dengan shot terbanyak (179 shot) berada posisi terendah jika dikomparasikan dengan film lainnya.

\begin{tabular}{|l|l|l|}
\hline \multicolumn{3}{|c|}{ Medium Long Shot (MLS) } \\
\hline Al Kautsar & 110 shot & $14,1 \%$ \\
\hline $\begin{array}{l}\text { Nada dan Dakwah } \\
\text { Titian Serambut } \\
\text { Dibelah Tujuh }\end{array}$ & 134 shot & $18,3 \%$ \\
\hline
\end{tabular}

\begin{tabular}{|l|l|l|}
\hline $\begin{array}{l}\text { Ketika Cinta } \\
\text { Bertasbih I }\end{array}$ & 179 shot & $13,8 \%$ \\
\hline
\end{tabular}

f) Persentase skala full shot tidak mengikuti pola yang diprediksi. Titian Serambut Dibelah Tujuh mendominasi cukup signifikan.

\begin{tabular}{|l|c|c|}
\hline \multicolumn{3}{|c|}{ Full Shot (FS) } \\
\hline Al Kautsar & 95 shot & $12 \%$ \\
Nada dan Dakwah & 60 shot & $8,1 \%$ \\
$\begin{array}{l}\text { Titian Serambut } \\
\text { Dibelah Tujuh } \\
\text { Ketika Cinta } \\
\text { Bertasbih I }\end{array}$ & 154 shot & $18,7 \%$ \\
\hline
\end{tabular}

g) Perhitungan skala Long Shot pada film pertama dan terakhir Chaerul Umam tampak tidak mengalami perubahan yang berarti, namun tren menurun pada film-film pertengahan (1980-an dan 1990-an). Hasil persentase kembali menunjukkan hasil yang tidak diprediksi sebelumnya.

\begin{tabular}{|l|c|c|}
\hline \multicolumn{2}{|c|}{ Long Shot (LS) } \\
\hline $\begin{array}{l}\text { Al Kautsar } \\
\text { Nada dan Dakwah }\end{array}$ & 20 shot & $6,7 \%$ \\
$\begin{array}{l}\text { Titian Serambut } \\
\text { Dibelah Tujuh } \\
\text { Ketika Cinta } \\
\text { Bertasbih I }\end{array}$ & 40 shot & $4,8 \%$ \\
\hline
\end{tabular}

\section{c. Evaluasi style camera work}

a) Penggunaan teknik crane merupakan hal yang baru dalam film Chaerul Umam.

b) Konsistensi penggunaan zoom berakhir di penghujung tahun 1990-an. 
c) Penggunaan pan menjadi teknik yang mendominasi.

d) Secara keseluruhan, penggunaan camera movement turun hingga $10 \%$.

\section{SIMPULAN}

Perdebatan tentang keabsahan penelitian dengan pendekatan kualitatif (fenomenologi) dan kuantitatif (positivism) telah berlangsung hampir seumur ilmu pengetahuan itu sendiri. Namun, sebagai sebuah kajian akademis, kajian sinema seharusnya dapat menerapkan kedua pendekatan tersebut dalam penelitianpenelitian ilmiahnya. Dalam lingkup dunia sinema, usaha untuk mengkaji film dari perspektif yang berbeda adalah usaha yang sejak dahulu dilakukan oleh para tokoh realisme dan formalisme dalam tradisi klasik. Ontologi film menjadi pintu berbagai macam sudut pandang dalam melihat dan menganalisis film menjadikan film memperoleh predikat sebagai seni ketujuh dalam peradaban.

Neo-formalisme hadir dalam kajian sinema yang melihat film sebagai film mendeklarasikan bahwa film harus dikaji tanpa ada kaitan dari disiplin ilmu dan seni yang lain. Aliran ini dipelopori oleh Victor F. Perkins lewat bukunya Film as Film (1972), la mencari celah agar kita bisa menganalisa film dari sudut pandang yang paling ontologis. Dalam aliran NeoFormalisme terdapat dua arus utama yaitu arus 'film kognitif' yang dipelopori David Bordwell dan arus 'scientific realisme' yang diperkenalkan oleh Barry Salt. Keduanya sama-sama memandang bahwa film diproduksi melalui mode praksis, yang membedakan keduanya adalah sikap terhadap penggunaan interpretasi makna dalam narasi film.

Keputusan Salt menggunakan pendekatan Positivism dalam kajian filmnya memperkenalkan Statistical Style Analisis atau Stylometry. Melalui Stylometry, Salt menawarkan metode untuk mengukur tingkat validitas style dalam film. Sistem kerja analisis Salt menggunakan pendekatan-pendekatan statistik dasar untuk mengukur style film dan shot merupakan satuan style yang akan dihitung.

Penerapan Stylometry sangat diperlukan pengetahuan dan pemahaman tentang teknis dan teknologi pembuatan film, karenanya Salt memasukkan pendekatan ini kepada kriteria teori praksis. Adapun elemen perhitungan yang ia tawarkan adalah ASL (average shot length), shot scale, dan camera workmovement. Barry Salt tidak membatasi ruang peneliti untuk lebih kreatif dalam mengeksplore aspek teknis lainnya dalam film.

Hasil perhitungan style film-film sampel dengan metode Stylometry di pembahasan sebelumnya, menghasilkan perhitungan yang stabil dan akurat. Dari ketiga parameter formal yang dihitung (ASL, tipe shot, dan camera movement) 
dapat disimpulkan bahwa:

a) Faktor durasi berperan sangat penting untuk memperlihatkan peta komparasi dari keempat film sampel.

b) Medium Shot merupakan tipe shot yang paling mendominasi

c) ASL film Chaerul Umam adalah 6.6 detik per shot

d) Camera movement sangat dipengaruhi perkembangan teknologi, penggunaan zoom dan crane paling jelas terlihat.

Hasil perhitungan yang ditemukan mampu menunjukkan bahwa interpretasi terhadap estetika film tidak dapat mempengaruhi komposisi-komposisi style dalam film, karena itu hasil penelitian Statistical Style Analysis dapat disebut lebih stabil dibandingkan hasil-hasil analisis berbasis interpretasi teks-naratif.

\section{SARAN}

Banyaknya aspek style yang dapat dianalisis di luar narasi menjadikan analisis style film sangat bervariasi. Statistical Style Analysis ini memberi ruang cukup besar dalam mengeksplorasi style film dari berbagai perspektif. Apa yang telah dijabarkan melalui perhitungan style film Chaerul Umam sebagai sampel hanyalah sebagian kecil dari eksplorasi tersebut.

Eratnya hubungan antara style film dengan perkembangan teknologi perfilman seperti kamera, sound, lighting, editing, dll merupakan kendala tersendiri dalam penerapan metode Stylometry dalam kajian film nasional kita. Hal yang disebabkan oleh minimnya data mengenai perkembangan teknologi perfilman nasional. Karena itu, sangat diharapkan suatu saat aspek teknologi dalam kajian film Indonesia dapat dimasukkan sebagai landasan analisis film secara historis. Dengan demikian, kajian film-film nasiona dapat dilakukan dalam area yang lebih luas agar memperkaya wawasan perfilman nasional kita.

\section{DAFTAR ACUAN}

Buku:

Barker, Chris. 2000. Cultural Studies ; Teori dan Praktek, Yogyakarta : Bentang.

Bordwell, David. 1996. Post Theory : Reconstructing Film Studies, Wisconsin : The University Of Winconsin Press.

Bordwell, David \& Kristin thompson, Film Art : An Introduction, Fourth Edition

Eisenstein, Sergei. 1957. Film Form and The Film Sense, New York : Meridian Books.

Salt, Barry. 2009. Film Style and Technology : History and Analysis, London: Starword Publishing.

Salt, Barry. 2006. Moving Into Pictures. London : Starword Publishing.

Sugiyono. 2012. Metode Penelitian Kuantitatif, Kualitatif dan R\&D, Bandung : Alfabeta.

\section{Jurnal IImiah:}

O. Hasbiansyah. 2008. Pendekatan Fenomenologi: Pengantar Praktik Penelitian dalam IImu Sosial dan Komunikasi. Jurnal Media Tor, Vol.9, No.1, Juni 2008 


\section{CAPTURE}

Internet:

Ariansah, Mohamad. 2016. Teori Film dan Tirani Ontologis.

https://www.academia.edu/311907

16/Teori_Film_dan_Tirani_Metode

-Ontologis 